\title{
Ecological effects of climate change on little penguins Eudyptula minor and the potential economic impact on tourism
}

\author{
Peter Dann ${ }^{1, *}$, Lynda Chambers ${ }^{2}$ \\ ${ }^{1}$ Research Department, Phillip Island Nature Parks, PO Box 97, Cowes, Phillip Island, Victoria 3991, Australia \\ ${ }^{2}$ Centre for Australian Weather and Climate Research, GPO Box 1289, Melbourne, Victoria 3001, Australia
}

\begin{abstract}
Using a 40 yr demographic database of little penguins Eudyptula minor, we investigated anticipated impacts of climatic changes on the penguin population at Phillip Island, southeastern Australia, and the potential economic impact on the associated tourism industry over the next century. We project a small loss of penguin breeding habitat due to sea level rise, although breeding habitat is unlikely to be limiting over this period. However, some erosion in the vicinity of tourism infrastructure will undoubtedly occur which will have economic implications. We anticipate little direct impact of decreased rainfall and humidity. However, fire risk may increase, and extreme climate events may reduce adult and chick survival slightly. Warmer oceans are likely to improve recruitment into the breeding population but the effect on adult survival is unclear. Overall, many aspects of little penguin biology are likely to be affected by climatic change but no net negative effect on population size is projected from existing analyses. Ocean acidification has the potential to be a highly significant negative influence, but present assessments are speculative. Some of the predicted negative impacts can be addressed in the shortterm, particularly those resulting from expected changes to the terrestrial environment. Others, particularly in the marine environment, appear to have limited options for mitigation locally. In the absence of evidence indicating population decline, economic impact may be confined to issues for tourism infrastructure due to increased sea-levels during storm events.
\end{abstract}

KEY WORDS: Climate change $\cdot$ Resilience $\cdot$ Adaptation $\cdot$ Seabird $\cdot$ Southern Australia $\cdot$ Penguin

\section{INTRODUCTION}

Little penguins Eudyptula minor, the world's smallest penguin, occur throughout New Zealand and the southern coast of Australia. Up to 1500 little penguins come ashore each night on Summerland Beach, Phillip Island (Fig. 1), at the world-famous 'Penguin Parade'. This penguin colony has been carefully monitored and managed for $>40$ yr with many threats being addressed to ensure that the population remains secure (Dann 1992). The Penguin Parade is an iconic component of Victoria's tourism industry: in 2010 attracting 471680 domestic and international visitors, providing direct employment to 200 staff and contributing $>100$ million dollars in tourism to the region (PINP 2011). Therefore should a significant reduction in the number of penguins at the Penguin Parade occur, as a result of climate change, considerable flow-on effects to regional tourism revenue would be expected.

Climate variability and change are known to affect seabirds, both directly (e.g. heat-related mortality) and indirectly (e.g. through the impact of climate on food webs) (Ainley et al. 2010, Brown et al. 2010, Chambers et al. 2011). Within the Australian region, seabird responses to observed climatic change vary 


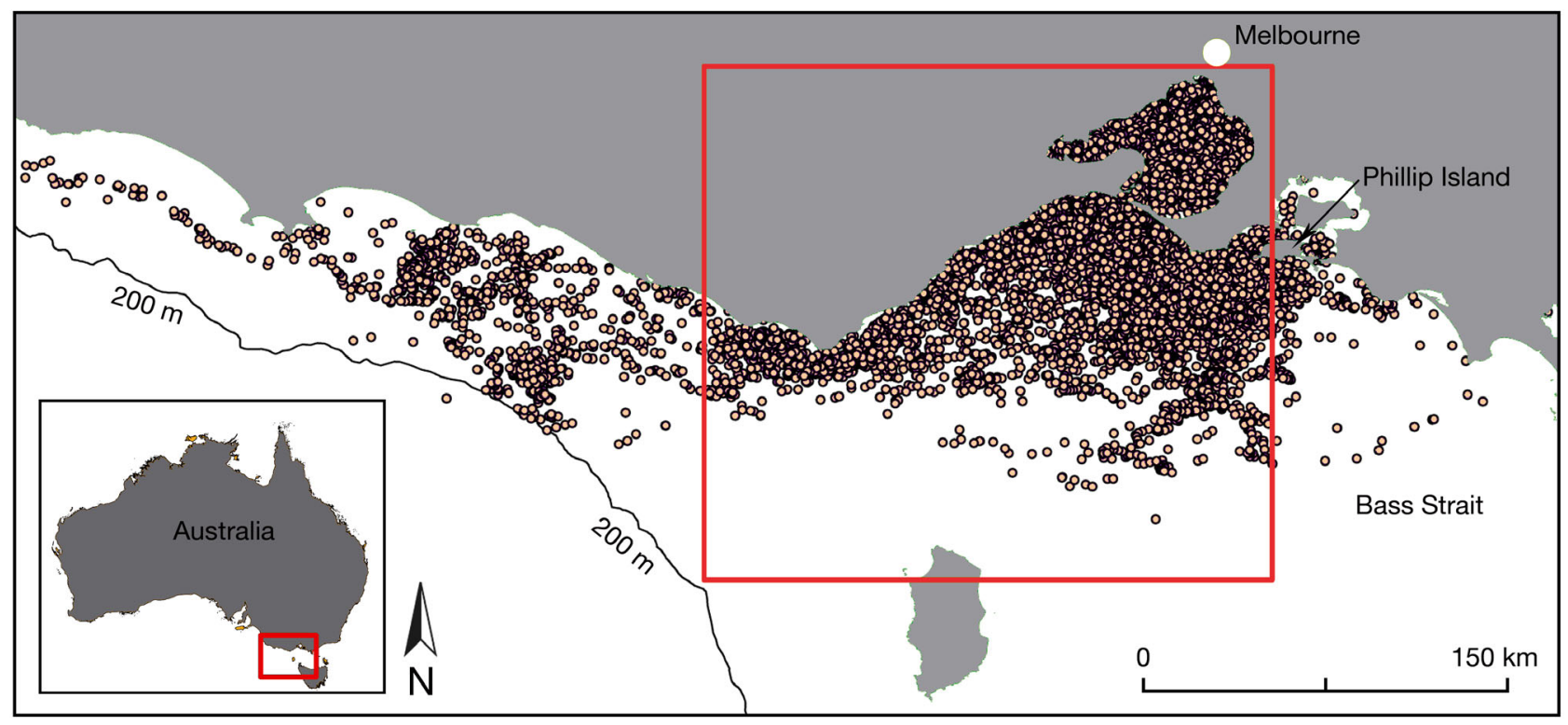

Fig. 1. Eudyptula minor. Location of Phillip Island. Purple dots: 20000 locations of $\sim 400$ satellite-tracked little penguins from Phillip Island during breeding (spring and summer) and non-breeding (winter) periods, included to illustrate areas frequented by penguins throughout the year. Red square: mean monthly sea surface temperature (SST) region used in the analyses of its effects on productivity and survival of penguins

by location and species (Chambers et al. 2011). In Western Australia, for example, breeding distributions of tropical seabirds shifted southward as regional sea-surface temperatures (SST) increased (Dunlop 2009), and changes have been observed in seabird breeding timing and reproductive success (Dunlop 2009, Surman \& Nicholson 2009), including for the little penguin (Cannell et al. 2012). Warmer SSTs, associated with the El Niño Southern Oscillation (ENSO), have also been associated with reductions in seabird populations on the Great Barrier Reef (Heatwole et al. 1996, Batianoff \& Cornelius 2005). Increased SSTs are believed to reduce prey availability to seabirds through decreased productivity at lower trophic levels and/or movement of forage fish or subsurface predators, either horizontally or vertically (Peck et al. 2004, Erwin \& Congdon 2007, Devney et al. 2010). Strong winds and severe storms also affect seabird breeding participation, success of breeding and mortality (King et al. 1992, Garnett et al. 2010).

Long-term datasets are central to understanding how species respond to climate change (Poloczanska et al. 2007). The datasets available for little penguins on Phillip Island are unusual in their durations (since 1968 for some parameters, including breeding timing and success, adult and fledgling mass and survival data) and allow sophisticated insights into this species' likely responses to climate change.
Using these penguin datasets and the scientific literature, we investigated likely impacts of 5 areas of projected climate changes on little penguins and their habitat on Phillip Island: (1) sea-level rise, (2) decreased rainfall (and humidity), (3) ambient air temperature rise, (4) SSTs in Bass Strait and (5) ocean currents (including thermoclines and ENSO events) and other potential drivers including winds and ocean acidification. The climatic effects may act directly on the physiology, behaviour and survival of penguins, or indirectly, including factors operating on the ecology and behaviour of their prey or on primary and secondary productivity in Bass Strait. Based on these results we evaluated the potential flow-on economic impacts and recommend, within adaptation options for the region, actions to increase the resilience of the little penguin colony.

\section{OBSERVED AND PROJECTED CHANGES IN THE LOCAL CLIMATE}

To place in context the anticipated effects of climate change on little penguins, we first considered observed and projected changes to the local climate system. The climate projections used incorporated the results of the Intergovernmental Panel on Climate Change (IPCC 2007) and Australian Climate Change projections (CSIRO \& BoM 2007). We considered 3 emissions sce- 
narios, incorporating up to 23 global climate models (IPCC 2007, DSE 2008): B1 scenario (lower emissions), A1B (medium emissions) and A1F1 (higher emissions). Recent evidence suggests that some critical parameters are tracking close to the worst-case scenarios (Richardson et al. 2009, Steffen 2009).

\subsection{Recently observed climate changes in the region}

\subsubsection{Surface air temperature}

Air surface temperatures in the Port Phillip/Western Port region during 1998 to 2007 were $\sim 0.4^{\circ} \mathrm{C}$ warmer, compared to the 1961-1990 average (DSE 2008), the largest change occurring during summer $\left(\sim 0.5^{\circ} \mathrm{C}\right)$. The mean number of days with temperatures $>35^{\circ} \mathrm{C}$ increased, while there were fewer cold nights (minimum temperatures $<5^{\circ} \mathrm{C}$ ).

By 2030 annual average temperatures in the region are projected to increase by $\sim 0.8^{\circ} \mathrm{C}$ (range of uncertainty 0.6 to $1.1^{\circ} \mathrm{C}$, medium emissions scenario; DSE 2008). By 2070 the projected increase is $\sim 1.3^{\circ} \mathrm{C}(0.9$ to $1.8^{\circ} \mathrm{C}$, lower emissions scenario) or $\sim 2.5^{\circ} \mathrm{C}(1.7$ to $3.5^{\circ} \mathrm{C}$; higher emissions scenario). The number of days with temperatures $>35^{\circ} \mathrm{C}$ is expected to double by 2030 and triple by 2070 , and an increase in the incidence of drought and heat waves is anticipated (DSE 2008).

\subsubsection{Precipitation, humidity and fire weather}

Since 1998 annual averaged rainfall in the Port Phillip/Western Port region has declined by $14 \%$, compared to the period 1961-1990 (DSE 2008), and the number of days on which rain fell also decreased (15 fewer per year).

By 2070 annual average rainfall is projected to decrease by $\sim 6 \%(0-12 \%$, lower emissions scenario) or $11 \%(0-23 \%$, higher emissions scenario) (DSE 2008). Decreased rainfall and increased evaporation rates are likely to reduce stream flows. Fewer days of rainfall are likely to result in more droughts; however, the intensity of heavy daily rainfall is expected to rise in most seasons (DSE 2008). Annual average relative humidity is also likely to decrease (DSE 2008).

Increased frequency of drought, rainfall declines and increased extreme temperatures are likely to increase fire risk. More dangerous fire weather days have been observed in recent decades (Lucas et al. 2007), and the length of the fire season may be increasing. An increase in dangerous fire weather days are also expected in the future, along with a longer fire season (C. Lucas [Bureau of Meteorology, Australia] pers. comm.).

\subsubsection{Sea surface temperature and ocean currents}

Australian oceans are warming, particularly off the south-west and south-east coasts. The southward flow of east coast currents have strengthened and are projected to continue to warm by 1 to $2^{\circ} \mathrm{C}$ by the 2030s, particularly off south-eastern Australia (Poloczanska et al. 2007, Lough 2009). By 2070, this warming is projected to be in the range of 2 to $3^{\circ} \mathrm{C}$. Greater ocean stratification is projected, as is a shallowing of the mixed layer (by 1 m) (Hobday et al. 2008), which is likely to reduce nutrient inputs from deep waters (Poloczanska et al. 2007).

ENSO is a major influence on Australia's climate, and its signals can be seen in the East Australian Current, though there is only low to medium confidence that it affects south-eastern waters (Holbrook et al. 2009). There is little evidence of a change in ENSO variability in response to global warming, and low confidence in future projections of changes in the amplitude or frequency of ENSO events, though there is greater confidence in background 'El Niñolike' patterns in the future (Holbrook et al. 2009). One measure of ENSO is the Southern Oscillation Index (SOI) (Allan et al. 1996). El Niño (La Niña) episodes are characterised by sustained negative (positive) SOI values, and are associated with weaker (stronger) Pacific Trade winds, generally reduced (increased) rainfall in eastern and northern Australia, and a cooler (warmer) SST in Australian waters.

\subsubsection{Sea level rise and storm surge}

Relative sea level around Australia has increased; since 1993 the rate of increase in south-eastern Australia was 2 to $4 \mathrm{~mm} \mathrm{yr}^{-1}$ (Church et al. 2009). Sea level is expected to continue to rise ( 0.06 to $0.17 \mathrm{~m}$ by 2030, lower- to higher-range emission scenarios) (McInnes et al. 2008). By 2070 the mid-range scenario is projected to be $0.32 \mathrm{~m}(0.15$ and $0.49 \mathrm{~m}$ : lower and higher emission scenarios).

The frequency of inundation and erosion of lowlying coastal areas on Phillip Island is expected to increase as a direct result of sea-level rise, and due to storm surges and storm tide levels, the degree of which will be dependent upon the local geomorphology 
(McInnes et al. 2008, Church et al. 2009). Soft substrates will be most affected, with an expected 50 to $100 \mathrm{~m}$ of horizontal erosion for every $1 \mathrm{~m}$ of sea-level rise (Bruun 1962). High, hard rocky coasts have low risk while low lying or softer landforms are more at risk (Sharples 2006). Other factors contribute to the extent of inundation, including local currents and sand accretion/erosion due to wind conditions or vegetation.

\subsubsection{Other climate variables}

Wind direction and velocity play an important role in transporting cooler water masses into central Bass Strait, and in the vertical mixing of the water column (Gibbs 1992, Sandery 2007). In the Western Port region, extreme wind speeds may decrease in summer and increase in winter (by $\sim 1 \%$, mid-range emissions scenario, by 2030) (Macadam et al. 2008). The projected weakening of winds in southern Australia during winter may reduce fish recruitment (Poloczanska et al. 2007).

Changes in ocean acidity levels represent a serious threat to calcifying organisms (Raven et al. 2005). pH is an important determinant of the growth rate of phytoplankton species; the direct effect of ocean acidification on calcifying zooplankton is to increase shell maintenance costs and reduce growth. Since 1750, ocean $\mathrm{pH}$ lowered by 0.1 units (a $30 \%$ increase in acid concentration), and by 2100 it is expected to decrease by a further 0.2 to 0.3 units (Howard et al. 2009).

\section{IMPLICATIONS OF CLIMATIC CHANGES FOR LITTLE PENGUINS}

\subsection{Ambient air temperature}

Projected increases in temperature extremes are likely to affect birds due to dehydration tolerance limits being reached and hyperthermia (McKechnie \& Wolf 2010). Seabirds are particularly vulnerable to heat stress during breeding and moult (Chambers et al. 2011), when they are on land and unable to avoid high daytime temperatures. Extreme temperatures and hyperthermia can also lead to reduced reproductive success (Yorio et al. 1995).

\subsubsection{Increase in hyperthermia}

Hyperthermia and, ultimately, adult mortality result from the direct effect of extreme high tempera- tures, but also indirectly through the loss of shading vegetation. Penguins reduce body temperature by hyperventilating, which is energetically expensive (Stahel \& Gales 1987). Oxygen consumption in nesting little penguins increases when ambient temperatures are $>26$ to $27^{\circ} \mathrm{C}$ (Baudinette et al. 1986). Presumably this is associated with higher rates of ventilation due to the increased need for evaporative cooling. Stahel \& Gales (1987) suggested that when burrow temperatures increase to $>35^{\circ} \mathrm{C}$, little penguins have a tolerance of only a few hours before body temperatures become dangerously high. Burrow microclimate determines the exposure to high temperatures, and this, in turn, is a reflection of the position and structure of the burrow and the insulation qualities of the soil and surrounding vegetation.

Of 416 recorded cases of mortality of adult penguins on land at Phillip Island between 1986 and 1989, 7 $(1.7 \%)$ were considered due to heat stress (Dann 1992). Based on a projected tripling of days with temperatures $>35^{\circ} \mathrm{C}$ by 2070 (the mid-range estimate for coastal regions of Western Port; DSE 2008), heat stress in the little penguin is likely to increase. At temperatures $>27^{\circ} \mathrm{C}$, the daily energy budgets of penguins is expected to increase in tandem with increasing temperatures, as the penguins expend energy to maintain core temperatures (Baudinette et al. 1986).

\subsubsection{Reduced breeding success}

Burrow temperature and humidity potentially influence penguin breeding success (Stahel \& Gales 1987) as well as adult survival. Burrow temperature varies with burrow type, depth and location, as well as with the surrounding and covering vegetation type and burrow structure (Ropert-Coudert et al. 2004). Little penguins readily use artificial boxes for breeding (Stoklosa et al. 2012), which provides opportunities to manipulate burrow microclimate in order to study the effects of this (Ropert-Coudert et al. 2004) as well to enhance penguin survival and breeding success.

\subsection{Decreased rainfall and humidity}

Rainfall affects the breeding success and survival of seabirds directly, and has implications for the quality of breeding habitat, particularly the microclimate of burrows, fire risk and prey availability (Chambers et al. 2011). Rainfall appears to have relatively few direct effects on the survival or breeding success of 
little penguins. Eggs and chicks have been lost through infrequent (once every $20 \mathrm{yr}$ ) flooding of burrows at Phillip Island, but other direct evidence is not apparent.

\subsubsection{Fire risk}

Decreasing rainfall and humidity, together with increasing droughts and air temperature, suggest a future increase in fire risk in the penguin breeding habitat. Being burrow nesting species, little penguins are particularly vulnerable to fire due to their flightlessness, and reluctance to abandon nests or emerge during daylight. This species also appears to be maladapted to fire; it does not avoid fire and will remain near or under vegetation until severely burnt or killed (Chambers et al. 2009). Penguins have also been observed standing beside flames preening singed feathers, rather than moving away (Renwick et al. 2007).

Fire reduces the quality of breeding habitat through the destruction of vegetation and associated damage to burrow structure, erosion of soils and reduction in insulation of surviving burrows. The impact of fire varies with vegetation type, and fire has a greater impact in grassland and scrubland and less in succulent herbfields. It was noticeable from a fire on Seal Island in south-eastern Australia, that areas of succulent vegetation and the penguins living in them were largely unaffected by the fire whereas grassland breeding areas were severely burnt and many of the burrowing seabirds killed (Renwick et al. 2007).

In addition to wildfires, fire risk is also increased through above-ground powerlines, (Chambers et al. 2009). Accordingly most of the current fire risk on the Summerland Peninsula has been removed with the burial of all power lines. The risk of damage to penguins and habitat could be reduced further through strategic planting of fire-resistant indigenous vegetation. Since most of the viewing of penguins by tourists (and the associated infrastructure) occurs in $<10 \%$ of the colony, it is in the interests of maintaining the visitor experience and infrastructure that greater levels of fire protection are afforded to these areas in particular.

\subsubsection{Availability of food}

Little penguins eat fish and squid, particularly small clupeiform fish, such as anchovy Engraulis aus- tralis and pilchard Sardinops sagax (Cullen et al. 1992, Chiaradia et al. 2012). Anchovies form a significant dietary component for Phillip Island penguins, particularly in winter when they forage in Port Phillip Bay (McCutcheon et al. 2011). Freshwater input can improve fertilization and local planktonic production, crucial for the survival of some fish larvae. Lloret et al. (2004) showed that the timing of spawning in a Mediterranean anchovy ( $E$. encrasiculus) is influenced by freshwater inputs from the Ebro River in Spain. Therefore projected reductions in freshwater flows, due mainly to rainfall reductions, may lead to a reduction in anchovy productivity (Santojanni et al. 2006), and thus is important that any links between penguin survival or abundance, anchovy spawning and availability, and freshwater flows are quantified.

\subsection{Sea-level rise}

The effect of sea-level rise on seabirds is expected to vary with location and breeding habitat, with species nesting on high rocky islands expected to have lower risk levels than those nesting on low-lying or sandy parts of islands (Chambers et al. 2011). In addition the ability of seabirds to adapt to sea-level rise by moving inland may be constrained by coastal development and infrastructure (Erwin 1980, Chambers et al. 2011).

\subsubsection{Loss of penguin breeding habitat}

Rising sea level is likely to be a threat to bird species that nest on low-lying coastal areas as breeding sites are flooded or eroded (Galbraith et al. 2002). Fig. 2 illustrates the distribution of breeding penguins on the Summerland Peninsula. Approximately $27 \%$ of penguin breeding areas on Summerland Peninsula have a sandy shoreline and the remainder is rocky. The rocky shoreline is expected to show relatively little response to sea-level change in the short to medium terms but the sandy shorelines could move up to $50 \mathrm{~m}$ inland for every $1 \mathrm{~m}$ sea-level rise (Bruun 1962), largely by increased instability through increasing frequency and intensity of storm surges and high seas.

In the long-term, some loss of breeding habitat is expected to occur at Cowrie Beach and Cat Bay on the northern side of the Peninsula and on Summerland Beach on the southern coast (Fig. 2) due to rising sea-levels. However the impact of this loss of habitat $(<<1 \%$ of that available) is unlikely to be 


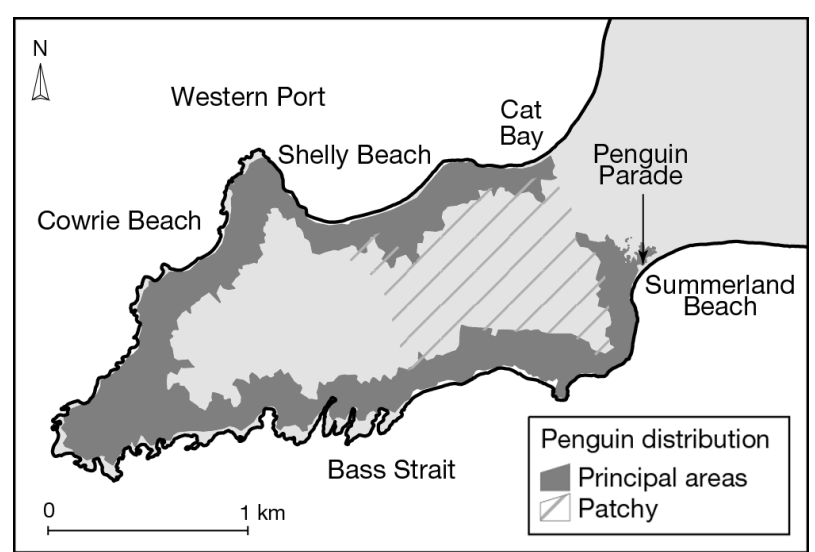

Fig. 2. Eudyptula minor. Distribution of little penguin breeding areas on the Summerland Peninsula, 2010. Main distribution of penguin burrows (shaded grey) and patchily distributed area (parallel lines) with breeding penguins. Sandy beaches: Cat Bay and Shelley, Cowrie and Summerland Beaches; remaining coastline consists of rocky shores

significant for penguin numbers over the next century since breeding habitat is not a limiting factor on Phillip Island (Dann \& Norman 2006), with plenty of suitable breeding habitat available inland at all of these sites. There may, however, be some negative implications for the nightly viewing of penguins by tourists. This area is likely to experience increased instability, albeit reduced by the protection afforded from storm surges and prevailing winds by an adjacent bluff.

\subsubsection{Penguin access to breeding sites and changes in beach profile}

Coastal erosion along beaches used by penguins for colony access is also likely to increase with climate change, together with the inundation of some low-lying breeding areas. Access to breeding sites is generally along tracks that have been used for decades. Access points are numerous but vary in quality, and the birds congregate at more sheltered sites with fewer physical hazards and reduced gradients into the hinterland. Sandy beaches are used wherever available and maybe preferred, as are creek outlets, particularly on sandy shore lines.

Marram grass Ammophila arenaria, a perennial European grass, was introduced to Phillip Island to stabilise dune erosion. Its spread has resulted in sand dunes of a significantly different shape to those produced by native vegetation (Hilton et al. 2005, Hilton 2006): generally large steep-faced dunes that are more susceptible to wave erosion. The resulting steep banks on the foredune can impede penguins crossing into breeding areas on or behind the primary dune. Currently Summerland Beach is actively managed by constructing temporary penguin tracks up the face of the dune, though this is a reactive rather than pro-active approach, and the problem is not always identified quickly. Replacement of marram grass with native species may improve penguin access now and into the future, as well as lessening the effects on beach gradients of anticipated increased wave activity.

\subsubsection{Changes to inshore productivity}

Changes in sea level are likely to reduce inshore productivity because the increase in water depth and consequent reduction in light availability to the sea bed will reduce the growth of subtidal marine plants (Short \& Neckles 1999). It is estimated that a $50 \mathrm{~cm}$ increase in sea level could result in a 30 to $40 \%$ reduction in growth of Zostera marina, a widespread Northern Hemisphere seagrass (Short \& Neckles 1999). It is anticipated that there will be some loss of productivity of inshore waters in Bass Strait, which may ultimately result in reduced food availability for penguins.

\subsection{Sea temperatures and ocean currents}

SSTs have a profound direct influence on Bass Strait pelagic ecosystem productivity (Brown et al. 2010) and accordingly, influence the demography of penguins, particularly the timing and success of breeding and survival.

\subsubsection{SSTs: timing and success of breeding}

Ocean temperatures may influence the timing and success of breeding of seabirds (Irons et al. 2008, Cullen et al. 2009). Penguin breeding may be affected by changes in marine productivity associated with SSTs and driven by oceanographic processes (Middleton \& Cirano 2002). Oceanic warming in south-eastern Australia is causing poleward shifts in species ranges, including species on which the penguins and their prey depend, and a shift in abundance toward species tolerant of warmer waters (Poloczanska et al. 2007, Last et al. 2011). 
SST variation has been associated with variation in the timing and success of breeding of little penguins (Cullen et al. 2009, Cannell et al. 2012). Phillip Island little penguins rarely travel outside Bass Strait (Collins et al. 1999, Hoskins et al. 2008) and therefore are dependent upon the waters of the Strait for all their food requirements. Cullen et al. (2009) predicted an early egg-laying date, higher average chick mass at fledging and a higher number of chicks produced per breeding pair when SSTs in Bass Strait were warmer than average in March (Fig. 3). Their models predict that an increase in SSTs is likely to lead to a reversal of the current trend towards later breeding (0.66 d yr $\left.{ }^{-1} ; \mathrm{p}=0.012\right)$ and suggest that growth of the little penguin colony on Phillip Island may increase, at least in the immediate future. A reanalysis of the little penguin breeding data, including the breeding season (2010/2011), indicates that there is no longer a statistically significant trend in breeding timing $(p=0.079)$, perhaps indicating that warming SSTs in Bass Strait may be already be having an affect. Based on the models of Cullen et al. (2009), the projected 2 and $3^{\circ} \mathrm{C} \mathrm{SST}$ rise for 2070 (Lough 2009) was used to provide a potential range of future laying dates (Table 1). However, it should be cautioned that this relationship may not continue to hold once Bass Strait SSTs exceed those experienced in the development of the model. Cullen et al. (2009) provide 2 hypotheses as to why warmer ocean temperatures lead to more successful penguin breeding, though both require further research. Warmer water leads to a longer breeding seasons and/or

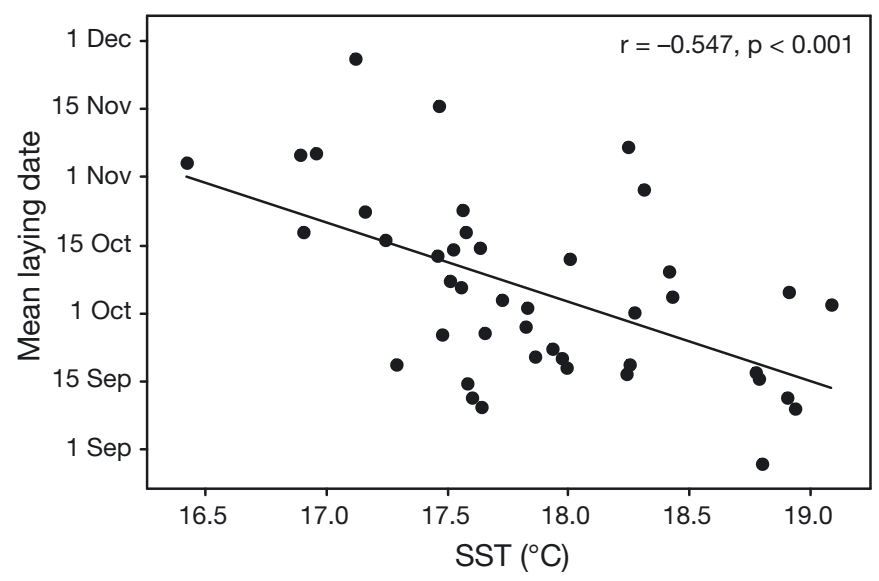

Fig. 3. Eudyptula minor. Relationship between timing of breeding of little penguins and mean March sea surface temperature (SST) for the region in Bass Strait bounded by $38^{\circ}-40^{\circ} \mathrm{S}, 143^{\circ}-145^{\circ} \mathrm{E}$ (as in Cullen et al. 2009 updated to include breeding seasons to 2010-2011). Laying date is modelled to be $17.6 \mathrm{~d}$ earlier for each degree increase in March SST $(p<0.001)$
Table 1. Eudyptula minor. Potential mean laying dates (MLD, mean $\pm \mathrm{SD}$; DOY: day of the year) of little penguins at Phillip Island under scenarios of a 2 and $3{ }^{\circ} \mathrm{C}$ rise in sea surface temperature in Bass Strait in March (see Section 3.4.1 for caveats)

\begin{tabular}{|c|c|c|}
\hline & MLD (DOY) & Range (DOY) \\
\hline $\begin{array}{l}\text { Current } \\
(1968-2008)\end{array}$ & $279 \pm 3.17 \quad[6$ Oct $]$ & $240-330$ \\
\hline $2^{\circ} \mathrm{C}$ rise & $244 \pm 1.75 \quad[31 \mathrm{Aug}]$ & $221-269$ \\
\hline $3^{\circ} \mathrm{C}$ rise & $226 \pm 1.75 \quad[14 \mathrm{Aug}]$ & $203-251$ \\
\hline
\end{tabular}

greater availability and quality of food (see Cullen et al. 2009 for further discussion).

\subsubsection{SSTs: juvenile (1st yr) survival}

Sidhu et al. (2012) found a strong positive relationship between first-year survival of penguins on Phillip Island and mean SST in Bass Strait in autumn of the year of breeding. Most chicks will have fledged by the beginning of autumn (Reilly \& Cullen 1982). Autumn is the peak mortality period for these young birds that are inexperienced in finding food (Dann et al. 1992), and SSTs are very likely to influence prey availability at this critical time. Both autumn SSTs and the east-west temperature gradient mentioned by Sidhu et al. (2012) are projected to rise as a result of global warming. However, it is currently uncertain as to what the net effect will be on first-year survival (Sidhu et al. 2012).

\subsubsection{SSTs: adult survival}

Sidhu (2007) examined the relationship between adult survival of little penguins breeding on Phillip Island and SSTs in south-eastern Australia. Adult survival probability in a given calendar year was best explained by the mean SSTs in the autumn and winter, and to a lesser extent, the summer of that year. The relationships were negative, suggesting that cooler SSTs in autumn and winter are associated with increased adult survival, which is the reverse of the relationship between SST and first-year survival. Dann et al. (1992) reported that adult mortality peaks in autumn after moult, and again in early spring. During the moult in February or March, adults fast for 15 to $20 \mathrm{~d}$ before returning to the sea to feed (Reilly \& Cullen 1983), suggesting that food supply before and after moulting plays a pivotal role in adult survival. 


\subsubsection{ENSO-related changes}

Higher first-year survival probability has been associated with lower values of the SOI, whereas the opposite was the case for adult survival (Sidhu 2007). Factors which affect adult survival have a greater impact on penguin population size than do those related to first-year survival (Dann 1992).

Highly negative (positive) SOI values indicate the presence of El Niño (La Niña) conditions, which are generally associated with lower (higher) SSTs in the Australian region. Sidhu (2007) noted that this result appears to contradict those obtained for local-scale SSTs and highlights the complexity of the effect that climatic conditions have on the survival of little penguins. Correspondingly, Fortescue (1998) reported that positive phases of the SOI were associated with increased adult survival from one season to the next. However, the SOI and survival may be stepped (i.e. changing at certain thresholds) rather than linear. For example, extremely high or low SOI values (La Niña or El Niño conditions) may affect penguin survival, whereas moderate values may have no effect (Sidhu 2007). Confidence in the relationships between adult survival and SST are lower than those for juvenile survival, and require further research to confirm the direction of the relationship.

\subsubsection{Increased stratification of water column on penguins}

The projected increase in ocean stratification may influence penguins directly through processes operating on their foraging efficiencies and indirectly through processes operating on primary and secondary productivity.

Mixing depth and mixing intensity in the surface ocean and the associated stratification are key factors for the production of phytoplankton (and, ultimately, higher trophic levels) because they fundamentally affect the supply of nutrients and light (Poloczanska et al. 2007). Predictions of an increase in stratification and a reduction in the depth of the mixed layer around most of continental Australia (Poloczanska et al. 2007) suggest a likely future reduction in productivity of pelagic ecosystems. Stratification may also have a direct effect on how successfully penguins feed. Ropert-Coudert et al. (2009) found an association between ocean stratification and foraging and breeding success of little penguins over a 2 yr period. A reduction in the thermocline was associated with a decrease in foraging and breeding success.
In summary, increased stratification of the water column may reduce productivity and, correspondingly, food availability for penguins in the long-term but, conversely, increase foraging efficiency of little penguins in the short-term.

\subsection{Other climate drivers}

\subsubsection{Wind}

Wind direction and velocity play important roles in the transport of cooler water masses into central Bass Strait and in the vertical mixing of the water column. The projected weakening of winds in southern Australia may change productivity patterns and reduce fish recruitment (Poloczanska et al. 2007) with corresponding implications for seabird survival and breeding success. Strong relationships between wind strength and recruitment exist for blue grenadier Macruronus novaezelandiae in outer continental shelf waters (Thresher et al. 1992). In south-eastern Australia reduced production of the jack mackerel Trachurus declivis off Tasmania resulted from decreased wind stress and subsequent decreases in large zooplankton (Harris et al. 1988).

Wind may play direct and indirect roles in determining the survival and breeding success of penguins. Ganendran et al. (2011) looked at the effect of wind direction and strength on survival of little penguins. First-year survival was negatively associated with strong easterly winds in the summer immediately following fledging, and positively associated with the number of strong southerly wind days in the winter before egg-laying. Annual adult survival was negatively associated with easterly winds in the summer of the previous year, and positively associated with northerly winds during autumn, when adults moult. The mechanisms by which strong wind events affect penguin survival are not fully understood but are possibly linked to wind-driven productivity in Bass Strait or to the mixing of the water column in penguin foraging areas, making prey acquisition more difficult (Ganendran et al. 2011).

\subsubsection{Ocean acidification}

It is difficult to predict how changes in ocean acidification will affect primary and secondary production in pelagic food chains (and, ultimately, penguins) with the current level of knowledge of the processes involved and the functioning of pelagic 
Table 2. Eudyptula minor. Summary of potential impacts of climatic change on little penguins, including a subjective analysis of the relative impact of the potential changes. (See Table 3 for details of how some potential impacts can be reduced or eliminated). SST: sea surface temperature, ENSO: El Niño Southern Oscillation

\begin{tabular}{|c|c|c|}
\hline $\begin{array}{l}\text { Predicted climate } \\
\text { change effect }\end{array}$ & Potential impacts & Relative impact \\
\hline Sea-level rise & $\begin{array}{l}\text { - Insignificant loss of breeding habitat } \\
\text { - Access to colonies disrupted on sandy shores } \\
\text { - Potential loss of inshore marine productivity in long-term }\end{array}$ & - Low (generally negative) \\
\hline $\begin{array}{l}\text { Decreased rainfall } \\
\text { (and humidity) }\end{array}$ & $\begin{array}{l}\text { - Increased fire risk leading to adult mortality } \\
\text { and some habitat loss } \\
\text { - Reduction in stream flows may affect spawning and } \\
\text { productivity of important prey species }\end{array}$ & $\begin{array}{l}- \text { Low? (generally negative) } \\
\text { (Some impacts can be reduced } \\
\text { through effective management) }\end{array}$ \\
\hline $\begin{array}{l}\text { Ambient } \\
\text { temperature rise }\end{array}$ & $\begin{array}{l}\text { - Slight increase in adult mortality } \\
\text { - Effects on breeding success not determined }\end{array}$ & $\begin{array}{l}- \text { Low (generally negative) } \\
\text { (Some impacts can be reduced } \\
\text { through effective management) }\end{array}$ \\
\hline $\begin{array}{l}\text { Increasing SST } \\
\text { and ENSO }\end{array}$ & $\begin{array}{l}\text { - Earlier and more productive breeding seasons in the short- } \\
\text { and medium-terms } \\
\text { - Greater survival in first year } \\
\text { - Possible increase in adult mortality but more work required }\end{array}$ & $\begin{array}{l}\text { - Moderate to high (generally } \\
\text { positive) }\end{array}$ \\
\hline $\begin{array}{l}\text { Increased ocean } \\
\text { stratification }\end{array}$ & $\begin{array}{l}\text { - Reduced marine productivity, but possible increase in } \\
\text { penguin feeding efficiency }\end{array}$ & $\begin{array}{l}\text { - Moderate? (Overall impact } \\
\text { uncertain) }\end{array}$ \\
\hline $\begin{array}{l}\text { Ocean acidification } \\
\text { and reduced average } \\
\text { wind strength }\end{array}$ & $\begin{array}{l}\text { - Decreasing winds likely to reduce fish recruitment and thus } \\
\text { food availability } \\
\text { - Increased ocean acidification may reduce food availability }\end{array}$ & $\begin{array}{l}\text { - Low-moderate? (generally } \\
\text { negative) }\end{array}$ \\
\hline
\end{tabular}

food webs. However, the physiology of fish and squid may be influenced by increasing $\mathrm{CO}_{2}$ levels in the oceans, since this influences tissue acid-base regulation and thus metabolism (Poloczanska et al. 2007).

Potential effects of acidification on penguins are likely to be through negative effects operating on primary and secondary productivity and on squid, such as Gould's Squid Notodarus gouldii, which is an important food source (Chiaradia et al. 2010).

The climatic drivers considered here are not exhaustive, but represent those that have currently been considered in the literature for this species. Future analyses could potentially include additional drivers, such as the Southern Angular Mode and multi-decadal variations.

A summary of the potential impacts of climatic change on penguins is provided in Table 2 .

There are many ways that resilience to climate change can be increased in the penguin population and we have made recommendations for actions likely to achieve this (Table 3). We also include a number of areas that need to be addressed before likely impacts can be evaluated, and suggest adaptation options.

\section{ECONOMIC IMPLICATIONS}

The Phillip Island Penguin Parade attracts nearly half a million visitors per year and contributes an estimated \$125 million of economic activity to the State of Victoria (Ernst \& Young 2012). The economy of the Bass Coast Shire, and of Phillip Island itself, is strongly linked to viable penguin tourism. More than half of the 1000-plus businesses in the Shire benefit directly from tourism (Marsden Jacob Associates 2008).

Although no significant penguin population decline is forecast in the short-term, we consider the most likely effect of reduced numbers would be on the visitor experience, and consequently on the income of the business. While we do not know the relationship between the number of penguins crossing the beach on a night and visitor satisfaction, any significant reduction in the numbers crossing at the nightly Parade is likely to have implications for the visitor experience. Certainly, the absence of penguins on any night would have flow-on effects, and ultimately result in the closure of the viewing facility for periods of time. This is most likely to happen after breeding (February to 
Table 3. Resilience building and recommendations for actions to buffer potential negative effects of climate change on little penguins. SST: sea surface temperature, ENSO: El Niño Southern Oscillation

\begin{tabular}{|c|c|}
\hline Effect & Action \\
\hline $\begin{array}{l}\text { Increasing air } \\
\text { temperatures }\end{array}$ & $\begin{array}{l}\text { - Increase appropriate vegetation cover in breeding habitat to reduce internal burrow temperatures } \\
\text { - Design artificial burrows with optimal microclimate for breeding success and adult energy budgets }\end{array}$ \\
\hline Decreasing rainfall & $\begin{array}{l}\text { - Increase appropriate vegetation cover in breeding habitat to reduce evaporation of soil moisture } \\
\text { during periods of decreased rainfall and to reduce erosion after high rainfall events } \\
\text { - Investigate the role of burrow humidity in determining the breeding success of penguins, } \\
\text { particularly hatching success and chick growth } \\
\text { - Reduce fire risk in breeding habitat through } \\
\text { 1. Planting fire resistant local vegetation, particularly succulent species } \\
\text { 2. Giving high priority to fire response planning and training } \\
\text { 3. Ensuring all power supply is underground } \\
\text { - Establish if relationships exist between stream inflows (and temperature) into Port Phillip Bay } \\
\text { and anchovy spawning and production }\end{array}$ \\
\hline Sea-level rise & $\begin{array}{l}\text { - Experimental removal of marram grass from some of the beach profile (replacing with native } \\
\text { species, e.g. Spinifex sericeus) to assess the likelihood of reducing storm-induced steep dunes } \\
\text { - Maintain high level visitor experience by encouraging colonisation of the eastern side of the } \\
\text { current breeding area at the Penguin Parade }\end{array}$ \\
\hline SST increase & $\begin{array}{l}\text { - Continue commitment to long-term studies of breeding, demography and foraging of little } \\
\text { penguins. Long-term datasets are key to documenting and understanding the response of species } \\
\text { to climate change, and the little penguin study at Phillip Island is one of the longest running } \\
\text { studies of a marine species in Australia } \\
\text { - Model the impact that shortening or lengthening the breeding season has on productivity } \\
\text { of penguins } \\
\text { - Review the linkages between SSTs in autumn and the timing and success of breeding in penguins, } \\
\text { focusing on linkages containing prey species } \\
\text { - Determine (with more confidence) the effect of SSTs and ENSO on adult survival } \\
\text { - Investigate the role of climate on fish recruitment (spawning and survival) in Bass Strait, including } \\
\text { coastal bays }\end{array}$ \\
\hline $\begin{array}{l}\text { Wind changes and } \\
\text { acidification }\end{array}$ & $\begin{array}{l}\text { - Develop a trophic model of the Bass Strait ecosystem to allow assessment of sensitivities to oceanic } \\
\text { variables for higher predators } \\
\text { - Determine the effects of wind on the foraging success of little penguins }\end{array}$ \\
\hline
\end{tabular}

April) or in mid-winter (July) when mean penguin numbers coming ashore each night are lower (Fig. 4). Marsden Jacob Associates (2008) considered the economic implications of a scenario of a significant decline in penguin numbers at the Parade in winter leading to the Park closing during these months, and tourism declining as tours are removed from itineraries. This scenario results in sizeable reductions in economic activity of around $\$ 18$ million of direct value, including flow-on (\$14.5 million decline in direct economic output, loss of 66 fulltime jobs for Bass Shire, losses relative to scenario with no economic impact), but care must be taken in interpreting the results, as the scenarios are purely hypothetical and there is considerable uncertainty regarding the magnitude and direction of any changes in the penguin population as a result of climate change.
However, in the absence of any significant indication that the penguin population will decline, the economic impact of climate change may be confined to issues for tourism infrastructure. Projections of sealevel rise and storm surge suggest that some erosion of the beach in the vicinity of the viewing stands and further east is likely, with implications for the infrastructure at the tourist viewing areas at the Penguin Parade. This implies that in the longer term, infrastructural change will be required to accommodate shoreline variation, but this is unlikely to pre-empt the normal infrastructure renewal schedule, presently renovated or replaced every 20 to $30 \mathrm{yr}$. Options for shifting Parade infrastructure, including viewing stands, to other sites on the Summerland Peninsula are unavailable due to lack of suitable alternative places with high numbers of penguins coming ashore and suitable sandy beaches for optimal viewing. 


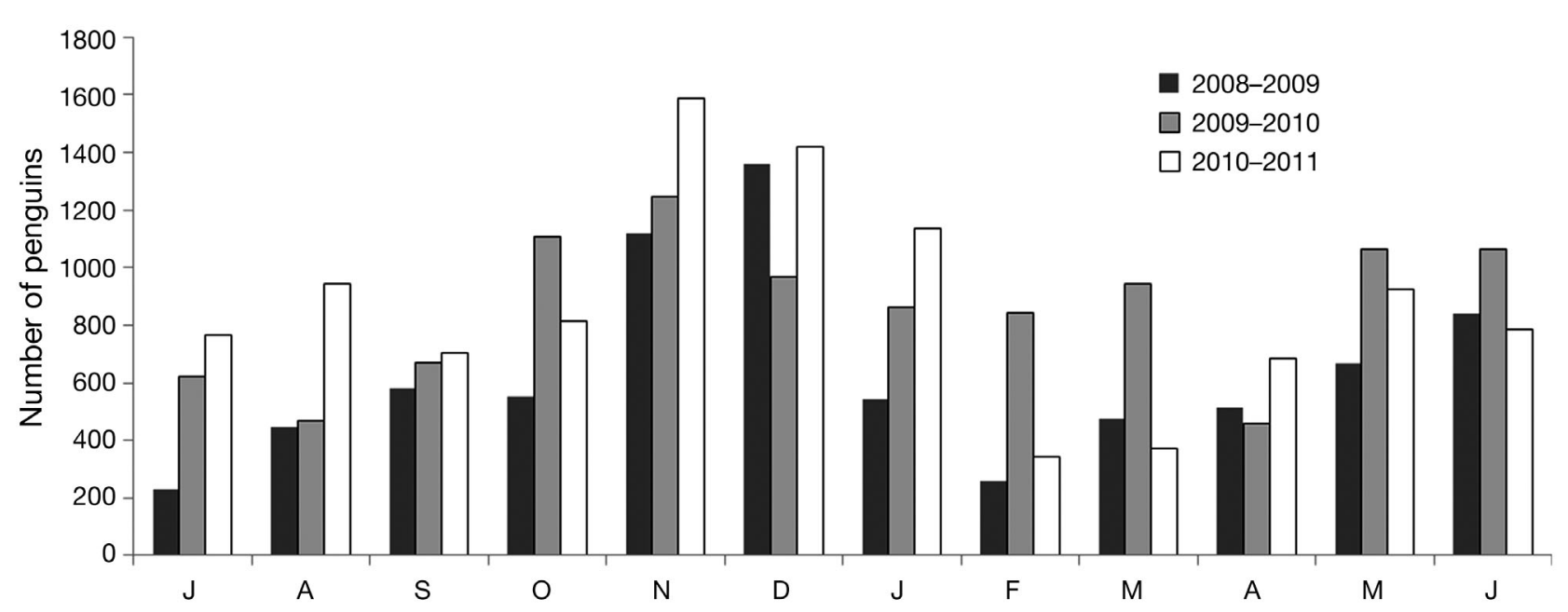

Fig. 4. Eudyptula minor. Mean number of little penguins coming ashore on Summerland Beach, Phillip Island, Australia, each month between July 2008 and June 2011. Egg laying at this location generally takes place between July and December; chick raising from August to February and moult from February to April

Acknowledgements. Thanks to G. Hunt (Western Port Greenhouse Alliance), R. Anderson and I. Mansergh (Department of Sustainability and Environment) for their support and guidance throughout the project. K. McInnes and E. Poloczanska (CSIRO), A. Chiaradia, R. Jessop, R. Dakin, L. Renwick, R. Kirkwood, M. Jackson and J. Fallaw (Phillip Island Nature Parks) and 3 anonymous reviewers, kindly commented on various drafts. D. Sutherland provided Fig. 2. D. Pleiter (WPGA) and R. Boyle (DSE) also provided assistance.

\section{LITERATURE CITED}

Ainley DG, Russell J, Jenouvrier S, Woehler E, Lyver PO, Fraser WR, Kooyman GL (2010) Antarctic penguin response to habitat change as earth's troposphere reaches $2^{\circ} \mathrm{C}$ above preindustrial levels. Ecol Monogr 80:49-66

Allan R, Lindesay J, Parker D (1996) El Niño Southern Oscillation and climate variability. CSIRO, Collingwood

Batianoff GN, Cornelius NJ (2005) Birds of Raine Island: population trends, breeding behaviour and nesting habitats. Proc R Soc Queensl 112:1-29

Baudinette RV, Gill P, O'Driscoll M (1986) Energetics of the little penguin, Eudyptula minor: temperature regulation, the calorigenic effect of food, and moulting. Aust J Zool 34:35-45

- Brown CJ, Fulton EA, Hobday AJ, Matear RJ and others (2010) Effects of climate-driven primary production changes on marine food webs: implications for fisheries and conservation. Glob Change Biol 16:1194-1212

Bruun P (1962) Sea-level rise as a cause of shore erosion. J Waterw Harbour Div 88:117-130

Cannell BL, Chambers LE, Wooller RD, Bradley JS (2012) Poorer breeding by little penguins near Perth, Western Australia is correlated with above average sea surface temperatures and a stronger Leeuwin Current. Mar Freshw Res. 63:914-925

Chambers LE, Renwick L, Dann P (2009) Climate, fire and little penguins. Strategic Assessment of the Vulnerability of Australia's Biodiversity to Climate Change. CSIRO, Melbourne
Chambers LE, Devney CA, Congdon BC, Dunlop N, Woehler EJ, Dann P (2011) Observed and predicted effects of climate on Australian seabirds. Emu 111:235-251

> Chiaradia A, Forero MG, Cullen M, Hobson KA (2010) Changes in diet and trophic position of a top predator ten years after a mass mortality of a key prey. ICES J Mar Sci 67:1710-1720

Chiaradia A, Forero MG, Hobson K, Swearer S, Hume F, Renwick L, Dann P (2012) Diet segregation between two colonies of little penguins Eudyptula minor in southeast Australia. Austral Ecol 37:610-619

Church JA, White NJ, Hunter JR, McInnes KL, Mitchell WM, O'Farrell SP, Griffin DA (2009) Sea level. In: Poloczanska ES, Hobday AJ, Richardson AJ (eds) Marine climate change impacts and adaptation report card for Australia 2009. NCCARF Publ 05/09

Collins M, Cullen JM, Dann P (1999) Seasonal and annual foraging movements of little penguins. Wildl Res 26:705-721

CSIRO, BoM (Bureau of Meteorology) (2007) Climate change in Australia. Tech Rep, available at www.climate changeinaustralia.gov.au (accessed 5 September 2011)

Cullen JM, Montague TL, Hull C (1992) Food of little penguins Eudyptula minor in Victoria: comparison of three localities between 1985 and 1988. Emu 91:318-341

Cullen JM, Chambers LE, Coutin P, Dann P (2009) Predicting onset and success of breeding in little penguins Eudyptula minor from ocean temperatures. Mar Ecol Prog Ser 378:269-278

Dann P (1992) Distribution, population trends and factors influencing the population size of little penguins Eudyptula minor on Phillip Island, Victoria. Emu 91:263-272

$>$ Dann P, Norman FI (2006) Population regulation in little penguins Eudyptula minor: the role of intraspecific competition for nesting sites and food during breeding. Emu 106:289-296

> Dann P, Cullen JM, Thoday R, Jessop R (1991) Movements and patterns of mortality at sea of little penguins Eudyptula minor from Phillip Island, Victoria. Emu 91:278-286

Devney CA, Caley MJ, Congdon BC (2010) Flexibility of responses by parent and offspring noddies to sea-surface temperature anomalies. PLoS ONE 5:e11891 
DSE (Department of Sustainability and Environment) (2008) Climate change in Port Phillip and Western Port. Victorian Gov DSE, Melbourne

Dunlop JN (2009) The population dynamics of tropical seabirds establishing frontier colonies on islands off southwestern Australia. Mar Ornithol 37:99-105

Ernst \& Young (2012) Economic impact of Phillip Island Nature Parks. Rep Phillip Island Nature Parks, Phillip Island

Erwin RM (1980) Breeding habitat use by colonially nesting waterbirds in two mid-Atlantic US regions under different regimes of human disturbance. Biol Conserv 18:39-51

Erwin CA, Congdon BC (2007) Day-to-day variation in seasurface temperature reduces Sooty Tern (Sterna fuscata) foraging success on the Great Barrier Reef, Australia. Mar Ecol Prog Ser 331:255-266

Fortescue M (1998) The marine and terrestrial ecology of a northern population of the little penguin, Eudyptula minor, from Bowen Island, Jervis Bay. PhD thesis, University of Canberra

Galbraith H, Jones R, Park R, Clough J, Herrod-Julius S, Harrington B, Page G (2002) Global climate change and sea level rise: potential losses of intertidal habitat for shorebirds. Waterbirds 25:173-183

Ganendran L, Sidhu L, Catchpole EA, Dann P, Chambers L (2011) The effect of directional wind components on survival of little penguins Eudyptula minor. Aust NZ Ind Appl Math J 52:1012-1030

Garnett ST, Szabo J, Dutson G (2010) The action plan for Australian birds 2010. CSIRO, Collingwood

Gibbs C (1991) Oceanography of Bass Strait: implications for the food supply of little penguins Eudyptula minor. Emu 91:395-401

> Harris G, Davies P, Nunez M, Meyers G (1988) Interannual variability in climate and fisheries in Tasmania. Nature 333:754-757

Heatwole H, O'Neill P, Jones M, Preker M (1996) Long-term population trends of seabirds on the Swain Reefs, Great Barrier Reef. Tech Rep 12. CRC Reef Research Centre, Townsville

Hilton M (2006) The loss of New Zealand's active dunes and the spread of marram grass (Ammophila arenaria). NZ Geog 62:105-120

Hilton M, Duncan M, Jul A (2005) Processes of Ammophila arenaria (Marram Grass) invasion and indigenous species displacement, Stewart Island, New Zealand. J Coast Res 21:175-185

Hobday AJ, Poloczanska ES, Matear RJ (eds) (2008) Implications of climate change for Australian fisheries and aquaculture: a preliminary assessment. Rep Dep Clim Chang, Canberra, August 2008

Holbrook NJ, Davidson J, Feng M, Hobday AJ, Lough JM, McGregor S, Risbey JS (2009) El Niño-Southern Oscillation. In: Poloczanska ES, Hobday AJ, Richardson AJ (eds) A marine climate change impacts and adaptation report card for Australia 2009. NCCARF Publ 05/09

Hoskins AJ, Dann P, Ropert-Coudert Y, Kato A, Chiaradia A, Costa DP, Arnould JPY (2008) Foraging behaviour and habitat selection at sea in little penguins Eudyptula minor during the chick-guard stage of breeding. Mar Ecol Prog Ser 366:293-303

Howard WR, Havenhand J, Parker L, Raftos D, Ross P, Williamson J, Matear R (2009) Ocean acidification. In: Poloczanska ES, Hobday AJ, Richardson AJ (eds) A marine climate change impacts and adaptation report card for Australia 2009. NCCARF Publ 05/09

IPCC (Intergovernmental Panel on Climate Change) (2007) Climate change 2007: the physical science basis. Contribution of Working Group I to the Fourth Assessment Report of the Intergovernmental Panel on Climate Change. Summary for Policy makers. Cambridge University Press, Cambridge

> Irons D, Anker-Nilssen T, Gaston AJ, Byrd GV and others (2008) Fluctuations in circumpolar seabird populations linked to climate oscillations. Glob Change Biol 14: 1455-1463

King BR, Hicks JT, Cornelius J (1992) Population changes, breeding cycles and breeding success over six years in a seabird colony at Michaelmas Cay, Queensland. Emu 92:1-10

> Last PR, White WT, Gledhill DC, Hobday AJ, Brown R, Edgar GJ, Pecl G (2011) Long-term shifts in abundance and distribution of a temperate fish fauna: a response to climate change and fishing practices. Glob Ecol Biogeogr 20:58-72

- Lloret J, Palomera I, Salat J, Sole I (2004) Impact of freshwater input and wind on landings of anchovy (Engraulis encrasicolus) and sardine (Sardina pilchardus) in shelf waters surrounding the Ebre (Ebro) River delta (northwestern Mediterranean). Fish Oceanogr 13:102-110

Lough JM (2009) Temperature. In: Poloczanska ES, Hobday AJ, Richardson AJ (eds) A marine climate change impacts and adaptation report card for Australia 2009. NCCARF Publ 05/09

Lucas C, Hennessy K, Mills G, Bathols J (2007) Bushfire weather in southeast Australia: recent trends and projected climate change impacts. Consultancy Report prepared for The Climate Institute of Australia. Bushfire CRC, Melbourne

Macadam I, Ricketts J, Bathols J (2008) Climate change projections for the Western Port region. Impacts of climate change on human settlements in the Western Port region: an integrated assessment. CSIRO Marine and Atmospheric Research, Hobart

Marsden Jacob Associates (2008) The potential impacts of climate change on the Phillip Island little penguin colony: regional economic impacts. Marsden Jacob Associates, Camberwell

McCutcheon C, Dann P, Salton M, Renwick L, Gormley A, Arnould J (2011) Foraging range of little penguins during winter. Emu 111:321-329

McInnes KL, Macadam I, O'Grady J (2008) Effect of climate change on extreme sea levels in the Western Port region. Impacts of Climate Change on Human Settlements in the Western Port Region. CSIRO Marine and Atmospheric Research, Melbourne

McKechnie AE, Wolf BO (2010) Climate change increases the likelihood of catastrophic avian mortality events during extreme heat waves. Biol Lett 6:253-256

Middleton JF, Cirano M (2002) A northern boundary current along Australia's southern shelves: the Flinders Current. J Geophys Res 107:3129, doi:10.1029/2000JC000701

Peck DR, Smithers BV, Krockenberger AK, Congdon BC (2004) Sea-surface temperature constrains wedge-tailed shearwater foraging success within breeding seasons. Mar Ecol Prog Ser 281:259-266

PINP (Phillip Island Nature Park) (2011) Phillip Island Nature Parks' Annual Report 2010-11. PINP, Phillip Island

Poloczanska ES, Babcock RC, Butler A, Hobday AJ and oth- 
ers (2007) Climate change and Australian marine life. CRC Press, Cleveland, OH

Raven J, Caldeira K, Elderfield H, Hoegh-Guldberg O, and others (2005) Ocean acidification due to increasing atmospheric carbon dioxide. R Soc Policy Doc 12/05

Reilly PN, Cullen JM (1982) The little Penguin Eudyptula minor in Victoria. III. Dispersal of chicks and survival after banding. Emu 82:137-142

Reilly PN, Cullen JM (1983) The little penguin Eudyptula minor in Victoria. IV. The moult. Emu 83:94-98

Renwick L, Dann P, Thompson S (2007) Effect of fire on little penguins at Seal Island, south-eastern Australia. Abstracts. 6th Int Penguin Conf, Hobart

Richardson K, Steffen W, Schellnhuber HJ, Alcamo J and others (eds) (2009) Climate change: global risks, challenges and decisions. Synthesis Report. Congress, 10-12 March 2009, University of Copenhagen. http://climatecongress.ku.dk/pdf/synthesisreport

Ropert-Coudert Y, Cannell B, Kato A (2004) Temperature inside nest boxes of little penguins. Wildl Soc Bull 32: $177-182$

Ropert-Coudert Y, Kato A, Chiaradia A (2009) Impact of small-scale environmental perturbations on local marine food resources: a case study of a predator, the little penguin. Proc Biol Sci 276:4105-4109

Sandery PA (2007) Seasonal variability of water mass properties in Bass Strait: three-dimensional oceanographic modelling studies. PhD thesis, Flinders University, Adelaide

Santojanni A, Arneri E, Bernardini V, Cingolani N, Di Marco M, Russo A (2006) Effects of environmental variables on recruitment of anchovy in the Adriatic Sea. Clim Res 31:181-193

Sharples C (2006) Indicative mapping of Tasmanian coastal

Editorial responsibility: Tim Sparks,

Cambridge, UK vulnerability to climate change and sea-level rise: explanatory report, 2nd edn. Department of Primary Industries and Water, Hobart

Short FT, Neckles HA (1999) The effects of global climate change on seagrasses. Aquat Bot 63:169-196

Sidhu L (2007) Analysis of recovery-recapture data for little penguins. PhD thesis, The University of New South Wales, Australian Defence Force Academy, Canberra

Sidhu LA, Dann P, Chambers LE, Catchpole EA (2012) Seasonal ocean temperature and the survival of first-year little penguins Eudyptula minor in south-eastern Australia. Mar Ecol Prog Ser 454:263-272

Stahel C, Gales R (1987) Little penguins: fairy penguins in Australia. New South Wales University Press, Kensington

Steffen W (2009) Climate change 2009: faster change and more serious risks. Australian Government Department of Climate Change, Canberra

> Stoklosa J, Dann P, Huggins R (2012) Inference on partially observed quasi-stationary Markov chains with applications to multistate population models. J Agric Biol Environ Stat 17:52-67

Surman CA, Nicholson L (2009) The good, the bad, and the ugly: ENSO-driven oceanographic variability and its influence on seabird diet and reproductive performance at the Houtman Abrolhos, eastern Indian Ocean. Mar Ornithol 37:129-138

- Thresher RE, Nichols PD, Gunn JS, Bruce BD, Furlani DM (1992) Evidence for microbial production based on seagrass detritus supporting a planktonic food chain. Limnol Oceanogr 37:1754-1758

Yorio P, Bertellotti M, Quintana F (1995) Preference for covered nest sites and breeding success in Kelp Gulls Larus dominicanus. Mar Ornithol 23:121-128

Submitted: January 21, 2013; Accepted: August 20, 2013 Proofs received from author(s): November 13, 2013 